\title{
Isolation of Listeria monocytogenes from Goat Cheese Associated with a Case of Listeriosis in Goat
}

\author{
By I. Eilertz, M.-L. Danielsson-Tham, K.-E. Hammarberg, M. W. Reeves, J. Rocourt, \\ H. P. R. Seeliger, B. Swaminathan and W. Tham
}

Department of Food Hygiene, Faculty of Veterinary Medicine, University of Agricultural Sciences, Uppsala, Sweden.

\begin{abstract}
Eilertz, I., M.-L. Danielsson-Tham, K. E. Hammarberg, M. W. Reeves, J. Rocourt, H. P. R. Seeliger, B. Swaminathan and W. Tham: Isolation of Listeria Monocytogenes from goat cheese associated with a case of listeriosis in goat. Acta vet. scand. 1993, 34, 145149. - Listeria monocytogenes was isolated from the brain of a goat, which was euthanized due to listeriosis. A few weeks later a similar subtype of $L$. monocytogenes was isolated from an on-farm manufactured fresh cheese which did not contain any milk from the goat which had suffered from listeriosis. A similar subtype was also found on 1 of the shelves in the refrigerator where cheeses were stored. Prior to the onset of listeriosis, 1 fresh cheese had been made of milk from the actual goat, which may have excreted $L$. monocytogenes in her milk. Thus, the cheese made of this milk may have contaminated the shelves in the refrigerator which then has served as a Listeria reservoir for new cheeses during several weeks.
\end{abstract}

contamination; dairy.

\section{Introduction}

Cheeses have been the vehicle in at least 2 major outbreaks of listeriosis, one in the U.S.A. associated with Mexican-style cheese (142 cases, mortality rate $34 \%$ ) (James et al. 1985 , Linnan et al. 1988), and 1 in Switzerland (98 cases, mortality rate $27 \%$ ), where Vacherin Mont d'Or appeared to be the source (Bille \& Glauser 1988).

There are 2 conceivable main ways for $L$. monocytogenes to find its way to cheeses. This pathogen might be present in the raw milk delivered to the dairy. From investigations in North America, incidences of $0-7 \%$ in raw milk samples from farm bulk tanks have been reported (Lovett et al. 1987, Farber et al. 1988, Liewen \& Plautz 1988). Beckers et al. (1987) found an incidence of $4 \%$ in the region of
Utrecht, The Netherlands. L. monocytogenes might also be a part of the resident bacterial flora in the processing plant or ripening room of the dairy and thus constitute a risk of contamination for curd and cheeses. The organisms may originally have been introduced not necessarily by means of contaminated raw milk but also by soil, water or air.

The purpose of this study was to investigate if L. monocytogenes could be found in on-farm manufactured cheeses or in the environment on the actual goat farm subsequent to a case of listeriosis in a goat.

\section{Materials and methods}

On a goat farm in Sweden a goat which had given birth to a kid on March 16th, got ill with 
Table 1. Number of L. monocytogenes detected in goat cheeses made of raw milk.

\begin{tabular}{lcccc}
\hline $\begin{array}{l}\text { Cheese } \\
\text { no. }\end{array}$ & $\begin{array}{c}\text { Manufacturing } \\
\text { procedure }\end{array}$ & $\begin{array}{c}\text { Day of } \\
\text { manufacture }\end{array}$ & $\begin{array}{c}\text { Day of } \\
\text { analysis }\end{array}$ & $\begin{array}{c}\text { CFU of L. monocyto- } \\
\text { genes/g cheese }\end{array}$ \\
\hline 1 & No starter culture & April 20 & April 29 & $2.9 \times 10^{7}$ \\
2 & No starter culture & May 3 & May 4 & $1.6 \times 10^{3}$ \\
2 & $»$ & $»$ & June 5 & $1.8 \times 10^{7}$ \\
3 & Starter culture & May 3 & May 4 & $8.0 \times 10^{2}$ \\
3 & $»$ & $»$ & June 5 & $9.0 \times 10^{3}$ \\
\hline
\end{tabular}

$\mathrm{a}=$ Fermented whole milk (filmjölk; a dairy product marketed in Sweden) containing Leuconostoc cremoris, Streptococcus lactis, $S$. cremoris and $S$. diacetylactis.

convulsions on April 1st. The goat was treated by a veterinarian. She did not recover and was euthanized on April 5th. The diagnosis of listeriosis was confirmed by histopathological sections of the brain - which revealed meningoencephalitis - and by the isolation of $L$. monocytogenes from the brain. Before the goat developed symptoms some of her milk had been used together with milk from some other goats for making fresh cheese of raw milk without starter culture. This cheese, stored in a refrigerator, was eaten by the farmers without any indisposition. Unfortunately, no milk or cheese was left for investigation.Two weeks after the goat was euthanized a fresh cheese from the farm (newly made of raw milk and without starter culture) was sent to the Department of Food Hygiene, Uppsala, for Listeria detection (cheese no. 1, Table 1). In early May 2 newly made fresh cheeses were sent for analyses - both made of raw milk but 1 without and 1 with starter culture (cheeses no. 2 and 3, Table 1).

One week after the 2 last cheeses had arrived, the farm was visited by veterinary staff. Swab samples from the rectum and milk samples ("1 teat sample") were collected from all the 14 goats. Swab samples from the rectum were also taken from the family on the farm. Further, swab samples were taken from machine milking equipment (inside of teatcups, short pulse tubes and short milk tubes) and also from several places in the cheese manufacturing kitchen (sink, work tables, cheese making equipment, shelves in the refrigerator). The temperature in the refrigerator was $+3^{\circ} \mathrm{C}$. All swabs were put into tubes containing Listeria Enrichment Broth (LEB, Merck) supplemented with $1 \%$ agar. Also deep litter, collected at random in the goat stable, and rennet were sampled. All samples were transported by car in cooling bags and arrived at the laboratory within $5 \mathrm{~h}$.

\section{Milk samples.}

The milk samples were surface-inoculated in $0.1 \mathrm{ml}$ portions onto Listeria Selective Agar (LSA, Merck) and blood agar plates (Blood Agar Base from Oxoid containing 5\% v/v sterile defibrinated horse blood). Further, a 10 ml portion of each milk sample was centrifuged at $3000 \mathrm{rpm}$ for $10 \mathrm{~min}$. and from the sediment so formed a loopful $(10 \mu \mathrm{l})$ was surface-inoculated onto LSA and blood agar plates. The remaining sediment was diluted in $5 \mathrm{ml} \mathrm{LEB}$ and enriched at $+4^{\circ} \mathrm{C}$. From the enrichment, $0.1 \mathrm{ml}$ portions were taken out after 3 and 6 weeks and inoculated onto LSA- and blood agar plates.

\section{Cheese samples}

In order to quantify L. monocytogenes, a $10 \mathrm{~g}$ 
cube, consisting of material from both the surface and the interior, was cut from each cheese. Using a stomacher, the cube was macerated and blended with $90 \mathrm{ml}$ peptone water. Ten-fold serial dilutions $\left(10^{2}-10^{5}\right)$ of $1 \mathrm{ml} \mathrm{mac}$ erate were made in peptone water. From each dilution step, $0.1 \mathrm{ml}$ was surface-inoculated onto LSA plates. After storage of cheeses nos. 2 and 3 (Table 1) for an additional 4 weeks in the laboratory at $+4^{\circ} \mathrm{C}$, a further quantification was made.

\section{Rennet and deep litter samples}

Using a stomacher, $10 \mathrm{~g}$ of deep litter and 10 $\mathrm{ml}$ of rennet were each macerated/ blended with $90 \mathrm{ml}$ LEB. Ten-fold serial dilutions $\left(10^{2}\right.$ $10^{5}$ ) of $1 \mathrm{ml}$ mixture were made in peptone water. From each dilution step, $0.1 \mathrm{ml}$ was surface-inoculated onto LSA plates. The remaining mixture was enriched at $+4^{\circ} \mathrm{C}$. From the enrichment, $0.1 \mathrm{ml}$ portions were taken out after 3 and 6 weeks and inoculated onto LSA- and blood agar plates.

\section{Swab samples}

The swabs were used for surface inoculation onto LSA plates. After inoculation the swabs were replaced in the transport medium and stored at $+4^{\circ} \mathrm{C}$. Additional surface inoculation onto LSA plates was made after 3 and 6 weeks.

Isolation and identification of L. monocytogenes

All agar plates were incubated for 24 and $48 \mathrm{~h}$ at $37^{\circ} \mathrm{C}$. For each cheese sample, characteristic Listeria colonies were counted. Five of these were selected and streaked onto blood agar for control of purity. If characteristic Listeria colonies were present on the agar plates from the other samples, one colony was isolated per sample and streaked onto blood agar for control of purity. To be considered as
L. monocytogenes the following criteria had to be fulfilled: A Gram-positive short rod, growing with B-hemolysis on blood agar, "tumbling-motility" after incubation at $20^{\circ} \mathrm{C}$ for $24 \mathrm{~h}$, production of catalase, hydrolysis of esculine and acid from D-glucose and Lrhamnose but not from D-xylose or D-mannitol (Seeliger \& Jones 1986). The L. monocytogenes strains ( 1 from each positive sample) were also tested for acid from alpha-methylD-glucoside, alpha-methyl-D-mannoside, Larabinose, dextrin, D-lyxose, D-galactose, glycerol, glycogen, lactose, melezitose, melibiose, saccarose, D-sorbitol and sorbose. For the sugar fermentation tests a nutrient broth (pH 7.4) supplemented with $1 \%$ bromocresol purple was used. The inoculated tubes were incubated at $37^{\circ} \mathrm{C}$ for up to 7 days. The strains were serotyped and phagetyped according to reference methods (Seeliger \& Höhne 1979, Rocourt et al. 1985). Ribosomal DNA fingerprinting (ribotyping) was done as described by Altwegg et al. (1988) using the restriction enzyme EcoRI to restrict the genomic DNA of $L$. monocytogenes. Multilocus enzyme electrophoresis (MEE) was conducted as described by Selander et al. (1986) for 19 metabolic enzymes.

\section{Results}

L. monocytogenes was isolated from 5 objects ( 3 cheeses and 2 refrigerator shelves). Table 1 shows the number of colony forming units (CFU) determined in the cheeses. Both the $L$. monocytogenes strain isolated from the goat's brain and the 5 strains isolated and subtyped from cheeses and refrigerator shelves, respectively, belonged to serovar $1 / 2 \mathrm{~b}$. These strains were not phagetypable. All 6 strains were indistinguishable by MEE and ribotyping. All strains produced acid from alpha-methyl-Dglucoside, alpha-methyl-D-mannoside, glycerol (weak reaction), melezitose and saccarose. 
Three of the 6 strains also produced acid from lactose (the strain from the goat's brain, the strain from cheese no. 3 and 1 of the 2 strains isolated from the refrigerator).

\section{Discussion}

The results obtained show that the L. monocytogenes strains isolated from the diseased goat, from cheese no. 3 and from 1 shelf in the refrigerator were of a similar subtype. It must be pointed out that this cheese was made several weeks after the goat with listeriosis was euthanized and the cheese did not contain any milk from this goat. It is therefore suggested that the goat euthanized due to listeriosis may have excreted L. monocytogenes in her milk. Prior to the onset of listeriosis, one fresh cheese had been made of milk from this goat. This cheese was stored in a refrigerator which may then have served as a Listeria reservoir for new cheeses during several weeks. Six isolated L. monocytogenes strains belonged to the same serovar $(1 / 2 b)$ and were indistinguishable by the used MEE and ribotyping methods. This does not exclude a common source of these strains. The distribution of $L$. monocytogenes in the environment of an offfarm dairy making goat cheese in England has been highlighted by McLauchlin et al. (1990).

\section{Acknowledgement}

The financial support provided by the Swedish Council for Forestry and Agricultural Research is gratefully acknowledged.

\section{References}

Altwegg M, Alltwegg-Bissig R, Demarta A, Peduzzi $R$, Reeves $M W$, Swaminathan B: Comparison of four typing methods for Aeromonas species. J. diarrhoeal. Dis. Res. 1988, 6, 88-94.

Beckers HJ, Soentoro PSS, Delfgou-van Asch EHM: The occurrence of Listeria monocytogenes in soft cheeses and raw milk and its resistance to heat . Int. J. Food Microbiol. 1987, 4, 249-256.

Bille J, Glauser M-P: Listeriose-Situation in der Schweiz (Listeriosis in Switzerland). Bulletin des Bundesamtes für Gesundheitswesen /Bulletin de l'Office fédéral de la santé publique. 1988, no 3, 28-29.

Farber JM, Sanders GW, Malcolm SA: The presence of Listeria spp. in raw milk in Ontario. Can. J. Microbiol. 1988, 34, 95-100.

James SM, Fannin SL, Agee BA, Hall B, Parker E, Vogt J, Rung G, Williams J, Lieb L, Salminen C, Prendergast $T$, Werner SB, Chin J: Listeriosis outbreak associated with Mexican-style cheese. MMWR 1985, 34, 357-359.

Liewen MB, Plautz, MW: Occurrence of Listeria monocytogenes in raw milk in Nebraska. J Food Prot. 1988, 51, 840-841.

Linnan MJ, Mascola L, Dong Lou X, Goulet V, May $S$, Salminen $C$, Hird DW, Yonekura LM, Hayes $P$, Weaver R, Audurier A, Plikaytis BD, Fannin SL, Kleks A, Broome CV: Epidemic listeriosis associated with Mexican-style cheese. N. Engl. J. Med. 1988, 319, 823-828.

Lovett J, Francis DW, Hunt JM: Listeria monocytogenes in raw milk - Detection, incidence and pathogenicity. J. Food Prot. 1987, 50, 188 -192.

McLauchlin J, Melody H, Greenwood H, Pini PN: The occurrence of Listeria monocytogenes in cheese from a manufacturer associated with a case of listeriosis. Int. J. Food Microbiol. 1990, 10, 255-262.

Rocourt J, Audurier A, Courtieu AL, Durst J, Ortel $S$, Schrettenbrunner A, Taylor AG: A multi-centre study on the phage typing of Listeria monocytogenes. Zentralbl. Bakteriol. Mikrobiol. Hyg. [A] 1985, 259, 489-497.

Seeliger HPR, Höhne K: Serotyping of Listeria monocytogenes and related species. In: Bergan T, Norris J (eds.): Methods in Microbiology. Academic Press, New York 1979 pp. 33-46.

Seeliger HPR, Jones D: Section 14: Genus Listeria. In: Sneath PHA (ed.): Bergey's Manual of Systematic Bacteriology. Vol 2. Williams \& Wilkins, Baltimore 1986 pp. 1235-1245.

Selander RK, Caugant DA, Ochman H, Musser JM, Gilmour MN, Whittam TS: Methods of multilocus enzyme electrophoresis for bacterial population genetics and systematics. Appl. environ. Microbiol. 1986, 51, 873-884. 


\section{Sammanfattning \\ Förekomst av Listeria monocytogenes $i$ getost förknippat med ett fall av listerios hos get.}

Listeria monocytogenes isolerades från hjärnan på en get som avlivats p.g.a. misstänkt listerios. Några veckor senare isolerades samma subtyp av L. monocytogenes från en färskost tillverkad på den aktuella gården. Osten innehöll inte mjölk från listerios-geten. Samma subtyp isolerades också från en hylla i kylskåpet, där ostarna förvarades. Före getens insjuknande hade en färskost tillverkats av bl. a. hennes mjölk. Det kan inte uteslutas att geten före symtomuppträdande utsöndrade $L$. monocytogenes med mjölken och att osten som tillverkades av mjölken kan ha kontaminerat kylskåpshyllorna. Kylskåpet kom sedan att utgöra en Listeria-reservoir, där nyinlagda ostar kontaminerades. Inga andra getter på gården utsöndrade $L$. monocytogenes med mjölk eller faeces vid undersökningstillfället.

(Accepted December 23, 1992).

Reprints may be requested from: Wilhelm Tham, Department of Food Hygiene, Faculty of Veterinary Medicine, Swedish University of Agricultural Sciences, P.O Box 7009, S-750 07 Uppsala, Sweden. 
